\title{
LEGAL OPINION:
}

\section{THE RIGHT TO PROPERTY FROM A HUMAN RIGHTS PERSPECTIVE}

\author{
Dr. Christophe Golay and Ms. Ioana Cismas ${ }^{1}$
}

\footnotetext{
${ }^{1}$ Together with Claire Mahon, Dr. Christophe Golay is the Joint Coordinator of the Project on Economic, Social and Cultural Rights at the Geneva Academy of International Humanitarian Law and Human Rights. Ms. Ioana Cismas is a PhD candidate at the Graduate Institute of International and Development Studies and a Researcher within the Project on Economic, Social and Cultural Rights. This legal opinion was commissioned by the International Centre for Human Rights and Democratic Development (Rights \& Democracy). The authors are grateful to Prof. Eibe Riedel, Prof. Andrew Clapham, Claire Mahon and Carole Samdup for comments on the earlier draft. Any errors or shortcomings that may remain are the sole responsibility of the authors.
} 


\section{TABLE OF CONTENTS}

INTRODUCTION

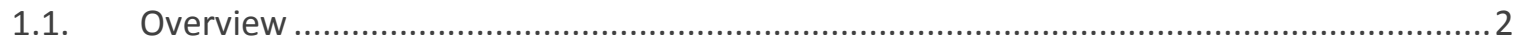

1.2. Genesis of the Right to Property and Certain Recurrent Issues .....................................2

THE RIGHT TO PROPERTY IN INTERNATIONAL LAW, REGIONAL TREATIES AND NATIONAL CONSTITUTIONS

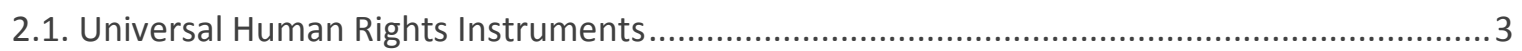

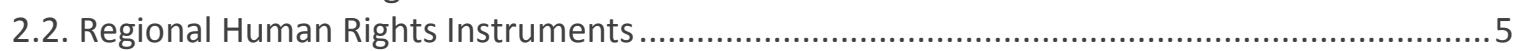

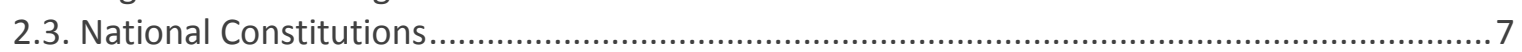

2.4. The Customary Law Character of the Right to Property ...................................................... 10

THE SCOPE AND CONTENT OF THE RIGHT TO PROPERTY AND CORRELATIVE STATES' OBLIGATIONS

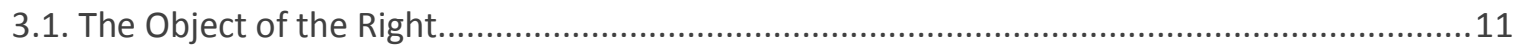

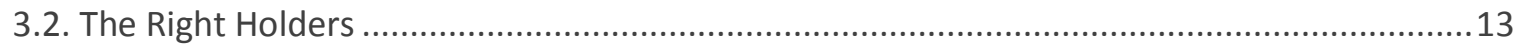

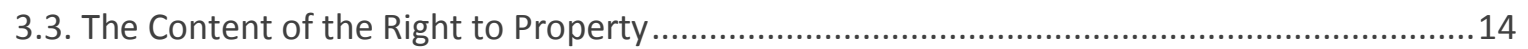

3.4. Compensation and the General Principles of International Law ............................................ 16

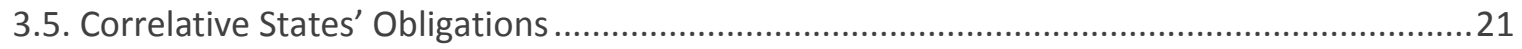

THE RIGHT TO PROPERTY AND THE PROTECTION OF ECONOMIC, SOCIAL AND CULTURAL RIGHTS

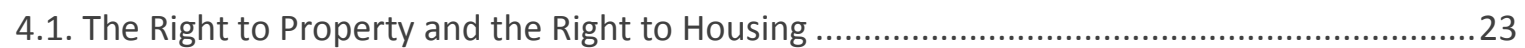

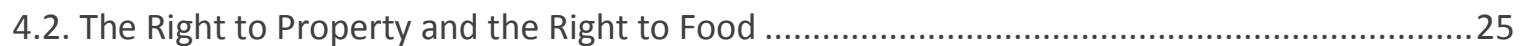

4.3. The Right to Property and the Right to Social Security .......................................................26

CONCLUSION

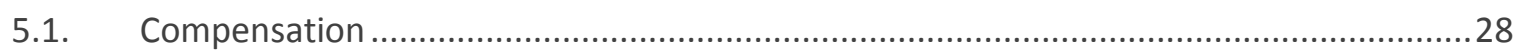

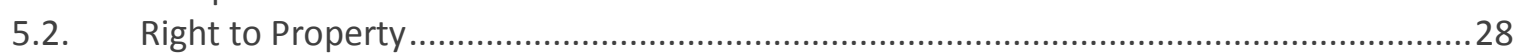

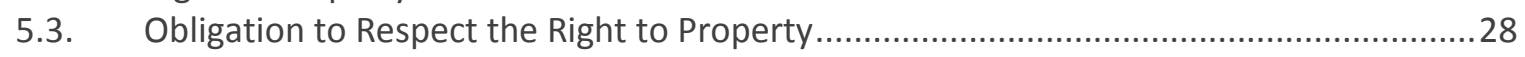

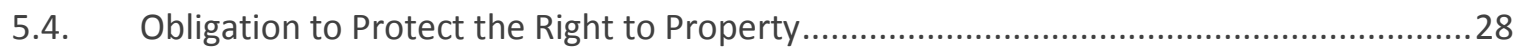

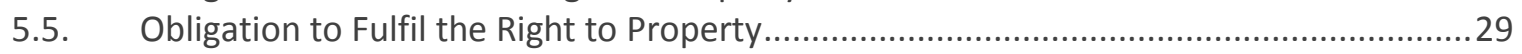

TABLE OF CASES 


\section{INTRODUCTION}

\subsection{Overview}

The aim of this legal opinion is to give a definition of the right to property from a human rights perspective. A survey of the right to property in international law, regional instruments and national constitutions will be followed by an analysis of the scope and content of the right to property and correlative States' obligations. Special attention will be paid to the role of the right to property in the realization of other human rights, in particular the rights to food, adequate housing and social security. Existing jurisprudence at the international, regional and national levels and doctrinal opinion will be used to define the right to property from a human rights perspective.

\subsection{Genesis of the Right to Property and Certain Recurrent Issues}

The right to property can be traced to the early philosophical writings leading to the French Revolution's Déclaration des droits de l'Homme et du citoyen ${ }^{2}$ and the US Bill of Rights ${ }^{3}$. Long after the first 18th century developments, the classification of the right to property as a human right continued to raise controversies.

One of the grounds for debate is the fact that property has been a privilege of the few and served in the past as a means of excluding the large mass of non-possessors from social and political life. ${ }^{4}$ The merit of this argument is that it pinpoints an intrinsic tension between the right to property as a civil liberty and its social function. The right to property, understood as a means of survival, is closely related to the realization of the right to life and of other human rights of the individual. At the same time, however, its limitation may be necessary for the realization of other human rights of other individuals. ${ }^{5}$ Western liberal tradition places this right among other freedoms, while its characteristics unequivocally would lead to its inclusion among economic, social and cultural rights.

Another line of argumentation suggests that certain characteristics of property, such as the possibility to sell, trade or destroy it, are in conflict with the inalienability principle characteristic of human rights. ${ }^{6}$ This kind of interpretation is perhaps tributary to a view of human rights solely through the lenses of civil and political rights. A comparison with economic, social and cultural rights - for example the right to food, where food itself can be sold, traded or destroyed - would make critics feel more at ease with the right to property as a human right, despite the alienable

\footnotetext{
${ }^{2}$ Article 2 of the Déclaration des droits de l'Homme et du citoyen, 1789, reads: "Le but de toute association politique est la conservation des droits naturels et imprescriptibles de l'homme. Ces droits sont la liberté, la propriété, la sûreté et la résistance à l'oppression." Article 17 reads: "La propriété étant un droit inviolable et sacré, nul ne peut en être privé, si ce n'est lorsque la nécessité publique, légalement constatée, l'exige évidemment, et sous la condition d'une juste et préalable indemnité."

${ }^{3}$ Amendment $\mathrm{V}$ of the US Bill of Rights states that: "No person shall (...) be deprived of life, liberty, or property, without due process of law; nor shall private property be taken for public use, without just compensation."

${ }^{4}$ F. Cheneval, "Property Rights as Human Rights", in H. de Soto and F. Cheneval, Realizing Property Rights, Rueffer \& Rub, Swiss Human Rights Book, Vol. I, 2006, at 11.

${ }^{5}$ For an example, see E. Wickeri and A. Kalhan, Land Rights Issues in International Human Rights Law, Institute for Human Rights and Business.

${ }^{6}$ F. Cheneval, "Property Rights as Human Rights", at 11.
} 


\section{THE RIGHT TO PROPERTY IN INTERNATIONAL LAW, REGIONAL TREATIES AND NATIONAL CONSTITUTIONS}

Despite persisting controversies, the formal inclusion of the right to property among the panoply of human rights, and therefore its legal basis, is clearly attested by several international and regional human rights instruments, as well as numerous national constitutions.

\subsection{Universal Human Rights Instruments}

A chronological approach to the international human rights instruments that proclaim the right to property must start with the Universal Declaration of Human Rights (UDHR), which in 1948 proclaimed in its Article 17 that "[e]veryone has the right to own property alone as well as in association with others" and that "[n]o one shall be arbitrarily deprived of his property." ${ }^{8}$ It is important to note that: the right applies to both individual and collective forms of ownership; unlike preceding drafts, the final article does not make any explicit mention to limitations of the right to property ${ }^{9}$; and the right is however not absolute, since deprivation of property is possible if such action is not arbitrary.

Adopted three years later, the Convention relating to the Status of Refugees, while not spelling out the right as such, contains several provisions concerning movable and immovable property rights of refugees. ${ }^{10}$ These provisions were mirrored in the Convention relating to the Status of Stateless Persons adopted in $1954 .{ }^{11}$ In accordance with the general agreement existing at that time on the right to property as a human right, the International Convention on the Elimination of All Forms of Racial Discrimination adopted in 1965 stipulates a general undertaking of State parties to eliminate racial discrimination and guarantee "the right to own property alone as well as in association with others" (Art. 5(v)), without entering into any discussion on limitations.

In this context, it is surprising that the International Covenant on Civil and Political Rights (ICCPR) and the International Covenant of Economic, Social and Cultural Rights (ICESCR), both adopted in 1966 , are silent on the right to property. ${ }^{12} \mathrm{~A}$ study of the travaux préparatoires explains that this silence, as Eibe Riedel suggested, originates in the antagonistic ideological views of the Western and Eastern blocs, as well as those of the North and South. ${ }^{13}$ It also clarifies that the non-inclusion of the

\footnotetext{
${ }^{7}$ See infra on the absence of the right to property from the two international Covenants adopted in 1966. See also C. Krause, "The Right to Property", in A. Eide, C. Krause, and A. Rosas (eds.), Economic, Social and Cultural Rights: A Textbook., 2nd revised ed., The Hague, Martinus Nijhoff, 2001, at 192-193.

${ }^{8}$ Universal Declaration of Human Rights adopted in 1948, Art. 17(1) and (2).

${ }^{9}$ See C. Krause, and G. Alfredsson, "Article 17", in G. Alfredsson and A. Eide (eds.), The Universal Declaration of Human Rights: A Common Standard of Achievement, The Hague, Martinus Nijhoff Publishers, 1999 359-378, at 364.

${ }^{10}$ Convention relating to the Status of Refugees adopted in 1951, Arts 13, 18, 19, 29 and 30.

${ }^{11}$ Convention relating to the Status of Stateless Persons adopted in 1954, Arts 13, 18, 19, 29 and 30.

${ }^{12}$ On the duality of the right and the discussion on whether it should have been included in the ICCPR or the ICESCR, see A. Rosas, "Property Rights", in A. Rosas, J.E. Helgesen, D. Goodman, The Strength of Diversity: Human Rights and Pluralist Democracy, The Hague, Martinus Nijhoff Publishers, 1992, 133-158, at 138.

${ }^{13}$ E. Riedel, Theorie der Menschenrechtsstandards, Berlin, Duncker \& Humbolt, 1986, at 39.
} 
right to property in the Covenants can by no means be equated with the denial of the right. ${ }^{14}$ In fact, at its tenth session, the Commission on Human Rights approved the first sentence of the draft article on the right to property as follows: "The States Parties to this Covenant undertake to respect the right of everyone to own property alone as well as in association with others" ${ }^{15}$ But objections persisted on the limitations of the right and restrictions of State action, in particular expropriation. The Annotations on the text of the draft International Covenants on Human Rights summarize best the mindset of the drafters: "(...) no one questioned the right of the individual to own property (...) it was generally admitted that the right to own property was not absolute" and "there was wide agreement that the right (...) was subject to some degree of control by the State" while "certain safeguards against abuse must be provided."16 Despite this consensual background, ideological and regional differences could not be bridged on the matter of limitations. The Commission on Human Rights adjourned the consideration of the issue sine die. As a result, property only appears in both Covenants as part of the non-discrimination clause. ${ }^{17}$

Several other core human rights treaties adopted after 1966 refer to property rights, despite the non-inclusion of the right to property in the two Covenants. Most of these instruments oblige States parties to ensure equality in respect to property ownership. Articles 15(2) and 16(1)(h) of the International Convention on the Elimination of All Forms of Discrimination against Women, adopted in 1979, proclaim the equal treatment of women and men in respect to ownership of property. The International Convention on the Protection of the Rights of All Migrant Workers and Members of Their Families, adopted in 1990, has the most detailed property clause, including conditions for permissible State interference:

No migrant worker or member of his or her family shall be arbitrarily deprived of property, whether owned individually or in association with others. Where, under the legislation in force in the State of employment, the assets of a migrant worker or a member of his or her family are expropriated in whole or in part, the person concerned shall have the right to fair and adequate compensation. (Art. 15)

The Convention on the Rights of Persons with Disabilities contains clauses on property rights under Articles 5(3) and 30(3). The latter provision is an acknowledgement of the necessary limitations of intellectual property rights as a means of realizing other human rights of persons with disabilities. ${ }^{18}$

Finally, the 1989 International Labour Organization Convention No. 169 concerning Indigenous and Tribal Peoples recognizes the rights of ownership and possession of the peoples concerned over the land they traditionally occupy, and the States' obligation to identify this land and guarantee effective protection of their rights of ownership and possession (Art. 14). Where the relocation of these

\footnotetext{
${ }^{14}$ See UN Docs. E/CN.4/SR.230-232; E/CN.4/SR.302, 303; E/CN.4/SR.413-418.

${ }^{15}$ See UN Doc. E/CN.4/SR.417, 418. For a discussion see also E. Riedel, Theorie der Menschenrechtsstandards, at 39-45.

${ }^{16}$ Annotations on the text of the draft International Covenants on Human Rights, 1 July 1995, UN Doc. A/2929, para. 197, 202, 206.

${ }^{17}$ ICCPR, Art. 2(1) provides that: "Each State Party to the present Covenant undertakes to respect and to ensure to all individuals within its territory and subject to its jurisdiction the rights recognized in the present Covenant, without distinction of any kind, such as race, colour, sex, language, religion, political or other opinion, national or social origin, property, birth or other status." According to ICESCR, Art 2(2): "The States Parties to the present Covenant undertake to guarantee that the rights enunciated in the present Covenant will be exercised without discrimination of any kind as to race, colour, sex, language, religion, political or other opinion, national or social origin, property, birth or other status."

${ }^{18}$ Article 30(3) reads: "States Parties shall take all appropriate steps, in accordance with international law, to ensure that laws protecting intellectual property rights do not constitute an unreasonable or discriminatory barrier to access by persons with disabilities to cultural materials." For intellectual property rights and workers and labour-related property rights, see also Krause, "The Right to Property", at 196.
} 
peoples is necessary, it shall take place with their free and informed consent, and they shall be provided with lands of equal quality and legal status or be fully compensated (Art. 16).

Soft-law instruments related to the right to property have been developed within the United Nations framework aiming to secure and safeguard property rights and related human rights. Some of these are evidence of the intrinsic link between the right to property, the right to housing and land rights. The United Nations Principles on Housing and Property Restitution, known as the Pinheiro principles, which have been endorsed by the Sub-Commission on the Promotion and Protection of Human Rights in 2005, are of particular relevance in the context of displacement. ${ }^{19}$ The Basic Principles and Guidelines on Development-based Evictions and Displacement developed by the United Nations Special Rapporteur on the right to housing are also relevant. ${ }^{20}$

Although it goes beyond the scope of this study, it should be noted that provisions of international humanitarian law offer protection to property rights in times of armed conflict. ${ }^{21}$

\subsection{Regional Human Rights Instruments}

In addition to the provisions discussed above concerning property rights at the universal level, the right to property is also recognized in regional human rights instruments.

The right to property has not been enshrined in the Convention for the Protection of Human Rights and Fundamental Freedoms, commonly referred to as the European Convention on Human Rights $(E C H R)^{22}$, but the first Article of its first Protocol, adopted in 1952, is entitled the "Protection of Property". It recognizes that:

Every natural or legal person is entitled to the peaceful enjoyment of his possessions. No one shall be deprived of his possessions except in the public interest and subject to the conditions provided for by law and by the general principles of international law.

The second paragraph of the same article provides the right of a State party "to enforce such laws as it deems necessary to control the use of property in accordance with the general interest or to secure the payment of taxes or other contributions or penalties." The context in which the ECHR and its Protocol No. 1 have been drafted - in the aftermath of authoritarian rule and abuse of power by the State - explains the need for safeguards on State actions. At the same time, States were aware of the social function that the right to property fulfils, and they were reluctant to submit political decisions, on issues such as expropriation or nationalization, to judicial review. ${ }^{23}$ However, at the end of the negotiations, it was felt that the balanced outcome, although not totally satisfactory,

\footnotetext{
${ }^{19}$ Housing and property restitution in the context of the return of refugees and internally displaced persons: Final report of the Special Rapporteur, Paulo Sérgio Pinheiro, UN Doc. E/CN.4/Sub.2/2005/17, 28 June 2005.

${ }^{20}$ Report of the Special Rapporteur on adequate housing as a component of the right to an adequate standard of living, Miloon Kothari, UN Doc. A/HRC/4/18, 5 February 2007, Annex 1. Other relevant soft-law instruments include the Guiding Principles on Internal Displacement developed by the first Representative of the Secretary-General on the human rights of internally displaced persons, F. Deng, in 1998 (UN Doc. E/CN/41998/53/Add.2) and the Basic Principles and Guidelines on the Right to Remedy and Reparation for Victims of Gross Violations of International Human Rights Law and Serious Violations of International Humanitarian Law, adopted by the General Assembly in its resolution 60/147.

${ }^{21}$ See for example Art. 46 of the Hague Convention (IV) Respecting the Laws and Customs of War on Land, 1907, and Article 53, Geneva Convention (IV) relative to the Protection of Civilian Persons in Time of War, 1949.

${ }^{22}$ On the debate as to whether to include the right to property in the ECHR, see Krause, "The Rights to Property", at 194. More generally on the competing visions of States and the different institutions of the Council of Europe during the drafting process of the ECHR, see S. C. Greer, The European Convention on Human Rights: Achievements, Problems and Prospects, New York, Cambridge University Press, 2006, at 18-19.

${ }^{23}$ T.R.G. Van Banning, The Human Right to Property, Antwerp, Intersentia, 2002, at 79.
} 
could be clarified in the future through jurisprudence. ${ }^{24}$ Indeed, as we will see below, the vast jurisprudence of the European Court of Human Rights (ECrtHR) is essential in understanding the content of the right and its relation with other rights. As an example here, we can indicate that the ECrtHR made clear that Article 1 of Protocol No. 1, using the term "possessions", "is in substance guaranteeing the right of property." 25

The American Convention on Human Rights (ACHR) upholds the right of everyone to the "use and enjoyment of his property" and lays down the possibility of subordinating this right to the interest of society, while at the same time specifying the restrictions on State actions (Article 21) ${ }^{26}$ The term "subordinate" ought to be regarded as linguistic evidence of the view championed by Latin American States regarding the importance of the social function of property. ${ }^{27}$ Moreover, the novel third clause of the article, prohibiting "usury and any other form of exploitation of man by man"28, establishes a clear relationship between individuals in respect to property, limiting everyone's right to property by the rights of others. It also clearly spells the duty of States to protect individuals against the property rights of others. ${ }^{29}$

The African Charter on Human and Peoples' Rights (AfCHPR) guarantees the right to property and outlines the public need and general interest of the community as legitimate grounds for limiting the right. The encroachment on the right must also be in "accordance with the provisions of appropriate laws". ${ }^{30}$ Legal scholars argue that among the many clawback clauses which exist in the AfCHPR, Article 14 contains the most far-reaching one. As such, the safeguards on State action remain very weak. ${ }^{31}$ At the same time, it is suggested that the clause is legitimate given the colonial past and the pattern of exploitation to which Africa was subjected. ${ }^{32}$ Article 13(3) grants equal access to public property and services to every individual, which is particularly important in the African context. ${ }^{33}$ Article 21 is also rooted in the colonial history of the continent, recognizing the right of all peoples to freely dispose of their wealth and natural resources. Since its relevance might become increasingly appealing to litigators given, for example, the recent large land appropriations by foreign States or companies, it will be quoted in full:

1. All peoples shall freely dispose of their wealth and natural resources. This right shall be exercised in the exclusive interest of the people. In no case shall a people be deprived of it.

2. In case of spoliation the dispossessed people shall have the right to the lawful recovery of its property as well as to an adequate compensation.

\footnotetext{
${ }^{24}$ T. R. G. van Banning, paraphrasing René Cassin, ibid, at 78-79.

${ }^{25}$ Marckx v. Belgium, Application No. 6833/74, Judgment of 13 June 1979, para 63. The Court based its assertion on the employment of the expression "use of property" in the second paragraph of the article, as well as on the travaux préparatoires where the drafters consistently refer to the right to property.

${ }^{26}$ These are "for reasons of public utility or social interest, and in the cases and according to the forms established by law" and compensation must be paid. American Convention on Human Rights adopted in 1969, Art. 21(1) and (2).

${ }^{27} \mathrm{An}$ analysis of the official records upholds this interpretation. T. R. G. van Banning, The Human Right to Property, at 62.

${ }^{28}$ ACHR, Article 21(3).

${ }^{29}$ T. R. G. van Banning, The Human Right to Property, at 62.

${ }^{30}$ The African Charter on Human and Peoples' Rights adopted in 1981, Art. 14.

${ }^{31}$ For a summary of scholars who share this view, see G. J. Naldi, "Limitation of Rights under the African Charter on Human and Peoples' Rights: The Contribution of the African Commission on Human and Peoples' Rights", 17 South African Journal on Human Rights, 2001 109-118.

${ }^{32}$ C. A. Odinkalu, "Implementing Economic, Social and Cultural Rights under the African Charter on Human and Peoples' Rights", in M. D. Evans, and R. Murray (eds.), The African Charter on Human and Peoples' Rights: the system in practice, 1986-2000, Cambridge, Cambridge University Press, 2002, at 191.

${ }^{33}$ E. A. Ankumah, The African Commission on Human and Peoples' Rights: Practice and Procedures, The Hague, Martinus Nijhoff Publishers, 1996, at 142.
} 
3. The free disposal of wealth and natural resources shall be exercised without prejudice to the obligation of promoting international economic cooperation based on mutual respect, equitable exchange and the principles of international law.

4. States parties to the present Charter shall individually and collectively exercise the right to free disposal of their wealth and natural resources with a view to strengthening African unity and solidarity.

States parties to the present Charter shall undertake to eliminate all forms of foreign economic exploitation particularly that practiced by international monopolies so as to enable their peoples to fully benefit from the advantages derived from their national resources. ${ }^{34}$

Article 26(1) of the 1995 Commonwealth of Independent States Convention on Human Rights and Fundamental Freedoms $\mathrm{s}^{35}$ generally follows the model set forth by other regional instruments stipulating the right to property subject to the usual limitations for deprivation, without however expressly mentioning the requirement of compensation. ${ }^{36}$

The (Revised) Arab Charter of Human Rights, which recently entered into force, provides that "[e]veryone has a guaranteed right to own private property, and shall not under any circumstances be arbitrarily or unlawfully divested of all or any part of his property." ${ }^{\prime 37}$ It appears that the "or" between "arbitrary" and "unlawful" suggest a disjunctive reading which could be in this case the equivalent of a clawback clause. The article being so general, it remains to be seen how the terms will be interpreted by the Arab Human Rights Committee and by a future Arab Court of Justice. Lastly, the Charter of Fundamental Rights of the European Union which became legally binding upon the entry into force of the Treaty of Lisbon in 2009 follows the model of Article 1 of Protocol I to the ECHR in respect to the protection of the right to property. ${ }^{38}$ In addition, it expressly stipulates that deprivation is subject to fair compensation "paid in good time". ${ }^{39}$

\subsection{National Constitutions}

It is not the intention and surely beyond the capacity of this legal opinion to review the constitutions of all States. Based on sources that have extensively dealt with the topic ${ }^{40}$, some patterns and some

\footnotetext{
${ }^{34}$ AfCHPR, Art. 21.

${ }^{35}$ The Commonwealth of Independent States Convention has raised controversies regarding the substantive and procedural protection it offers to human rights as well as in relation to the compatibility with the ECHR. See Parliamentary Assembly of the Council of Europe, Resolution 1249, 2001, "Coexistence of the Convention on Human Rights and Fundamental Freedoms of the Commonwealth of Independent States and the European Convention on Human Rights". The ECrtHR concluded that it had no competence to give an advisory opinion on the coexistence of the two instruments, see ECrtHR, Decision on the Competence of the Court to Give an Advisory Opinion, 2 June 2004.

${ }^{36}$ Meaning: "in the public interest, under a judicial procedure and in accordance with the conditions laid down in national legislation and the generally recognized principles of international law." Commonwealth of Independent States Convention on Human Rights and Fundamental Freedoms, Article 26(1). The second paragraph of Article 26 is rather unique and its application has not made the object of interpretation by the monitoring body of the Convention. It reads as follow: "However, the foregoing provisions shall in no way affect the right of the Contracting Parties to adopt such laws as they deem necessary to control the use of items withdrawn from general circulation in the national or public interest."

${ }^{37}$ Arab Charter on Human Rights adopted in 2004, Art. 31.

${ }^{38}$ Charter of Fundamental Rights of the European Union, 2009, Art. 17.

${ }^{39}$ Ibid.

${ }^{40}$ T. R. G. van Banning discusses the provisions of national Constitutions in respect of property rights extensively. T. R. G. van Banning, The Human Right to Property, at 139-146. See also Tom Allan, The Right to Property in Commonwealth Constitutions, Cambridge, Cambridge Univ. Press, 2000, at 36-82; The right of everyone to own property alone as well as in association with others: Completed final report submitted by Mr. Luis Valencia Rodríquez, Independent Expert, UN Doc. E/CN.4/1994/19, 25 November 1993.
} 
examples of constitutional clauses on property rights in both common and civil law systems will be discussed. Whereas the right to property appears to be the most often codified right in national constitutions, a variety of forms of codification can be observed, reaching from very detailed and context-specific provisions ${ }^{41}$ to general clauses. ${ }^{42}$ Of particular importance for this legal opinion is the fact that social aspects are comprised by constitutional clauses, and if so, in what way. As van Banning and others assert, many constitutions refer to what can be termed as social aspects: the "social function" ${ }^{43}$, the realization of other human rights in general, and socio-economic rights in particular. Moreover, some constitutions spell out the obligations of the State to protect and fulfil the right to property. ${ }^{44}$

Article 25 of the South African Constitution, adopted in 1996, is an elaborate example of the right to property functioning as a means of realizing other human rights, as well as of the role the State must play in this process. ${ }^{45}$ Property is guaranteed by the Constitution and "no law may permit arbitrary deprivation" ${ }^{46}$ Expropriation is permitted, if prescribed by law, in the public interest or for a public purpose and it is subject to compensation. ${ }^{47}$ Paragraph 4 defines the public interest as including "the nation's commitment to land reform, and to reforms to bring about equitable access to all South Africa's natural resources". Detailed provisions are outlined in respect to compensation so as to reflect "an equitable balance between the public interest and the interests of those affected" ${ }^{48}$ Paragraph 5 spells out the duty of the State to fulfil the right to property in respect to land: "The state must take reasonable legislative and other measures, within its available resources, to foster conditions which enable citizens to gain access to land on an equitable basis." The person or community whose tenure of land is insecure as a consequence of apartheid is entitled "either to tenure which is legally secure or to comparable redress." 49 Paragraph 8 spells the positive obligation of the State to enact legislation to give effect to the latter provision. Lastly, the Constitution proclaims a right to restitution for those who suffered forced removal during the apartheid regime. ${ }^{50}$

\footnotetext{
${ }^{41}$ For example, the article on the right to property of the Romanian Constitution of 1991, as amended in 2003 (Art. 44(4)), is to be understood in the context of the fall of communism where nationalization of property was based on criteria such as religion or political views. In addition, in the view of the accession to the European Union a clause has been introduced which reverses the previous prohibition of foreigners to own property, conditioning the right to property by the EU Accession Treaty stipulations and reciprocal conditions of other international treaties (Art.44(2)). For another context specific example, see the Constitution of China as amended in 2004, which has clauses on both private property and public property (Art. 12 and 13). For a very detailed article on the right to property, see Article 27 of the Constitution of Mexico, adopted in 1917.

42 The Swiss Constitution adopted in 1999 offers an example of a clause phrased in general terms: “1. La propriété est garantie. 2. Une pleine indemnité est due en cas d'expropriation ou de restriction de la propriété qui équivaut à une expropriation."

${ }^{43}$ Van Banning defines the social function as the obligation of the owner to use the property for the satisfaction of his needs but also the collective needs of society; as such, it refers to the rules regulating the relationship between the needs of the individual and the needs of society. The term predates the UDHR and the ICESCR and while related it should not be confused with a social right. T. R. G. van Banning, The Human Right to Property, at 147-148.

${ }^{44} \mathrm{lbid}$, at 147. See for example the Constitution of South Africa, Articles 7 and 25. See also The Human Rights Resource Center, The Circle of Rights, Module 18 - Land rights.

${ }^{45}$ The context in which the South African Constitution was adopted is essential. Geoff Budlendert notes that "forced removals were the only form of apartheid injustice which the new government was specifically instructed to redress as a matter of constitutional obligation", arguing that the resolution of land claims are of central importance in the process of national reconciliation. G. Budlender, "Restitution of Housing and Property Rights: Some Lessons from the South-African Experience", 19 Refugee Survey Quarterly 3, 2000, at 224.

${ }^{46}$ South African Constitution of 1996, Art. 25 (1).

47 Ibid, Art. 25 (2).

48 Ibid, Art. 25 (3).

49 Ibid, Art. 25 (6).

50 Ibid, Art. 25 (7).
} 
The Constitution of Brazil represents another clear example where the right to property has been interpreted as a modality of furthering other social and economic rights. The drafters explicitly mention the social function of property among the terms that qualify the inviolability of property ${ }^{51}$ and go on to stipulate that:

It is within the power of the union to expropriate on account of social interest, for purposes of agrarian reform, the rural property which is not performing its social function, against prior and fair compensation in agrarian debt bonds with a clause providing for maintenance of the real value, redeemable within a period of up to twenty years computed as from the second year of issue, and the use of which shall be defined in the law. ${ }^{52}$

There is no doubt that agrarian reform is a necessary step in realizing the right to food and the right to social security of small farmers and landless workers in Brazil ${ }^{53}$ and it is with this intention that the drafters of the Constitution put forward this limitation of the right to property. In addition to the articles that stipulate the social function of urban property and allow for expropriation under certain conditions $^{54}$, Article 183 of the Brazilian Constitution states that:

An individual who possesses an urban area of up to two hundred and fifty square meters, for five years, without interruption or opposition, using it as his or as his family's home, shall acquire domain of it, provided that he does not own any other urban or rural property.

The interplay between the right to housing and the right to property is very important here. While expropriation represents a limitation of the right to property so as to further the right to housing of others, the acquiring of property rights - hence a strengthening of the property regime - when previously no such rights existed, can again lead to the realization of the right to housing.

While the social function of property is said to be a constitutional development in Africa, Asia and Latin America during the last decades ${ }^{55}$, limitations based on social aspects of the right to property can also be found in Western Constitutions. The Constitution of Ireland, for example, after recognizing that the right to property is fundamental, admits that "the exercise of [the right to property] ought, in civil society, to be regulated by the principles of social justice" and that "[t]he State, accordingly, may as occasion requires delimit by law the exercise of the said rights with a view to reconciling their exercise with the exigencies of the common good. ${ }^{\prime 56}$ Germany's Grundgesetz states that: "Property entails obligations. Its use shall also serve the public good." ${ }^{\text {" }}$ Lastly, one should regard the prohibition of monopolies and the correlative duty of the State to protect in the context of the right to property's social function. And indeed, the United States has enacted legislation and continues to allocate considerable resources to prevent, control and dismantle monopolies. $^{58}$

\footnotetext{
${ }^{51}$ Constitution of the Federative Republic of Brazil of 5 October 1988, with the alterations introduced by Constitutional Amendments No. 1/92 through 57/08 and by Revision Constitutional Amendments No. 1/94 through 6/94, Article 5(XXIII). ${ }^{52}$ Ibid, Art. 184. See also Art. 186.

${ }^{53}$ See Report by the Special Rapporteur on the right to food, Mr. Jean Ziegler, on his mission to Brazil, UN Doc. E/CN4/2003/54/Add1, 3 January 2003.

${ }^{54}$ Constitution of the Federative Republic of Brazil of 5 October 1988, Art. 182.

${ }^{55}$ The Human Rights Resource Center, Circle of Rights.

${ }^{56}$ Bunreacht Na hÉireann of 1937, Article 43.2(1) and 2(2). (Emphases added.)

${ }^{57}$ Basic Law for the Federal Republic of Germany, promulgated by the Parliamentary Council on 23 May 1949, as amended by the Unification Treaty of 31 August 1990 and Federal Statute of 23 September 1990, Art. 14(2).

${ }^{58}$ For other examples of social aspects in the US property rights system, see G. S. Alexander, "The Social-Obligation Norm in American Property Law", 94 Cornell Law Review, 2008746 - 819.
} 


\subsection{The Customary Law Character of the Right to Property}

The review of provisions of international instruments, regional treaties and national constitutions reveal the universal recognition of the human right to property. It appears that generalized and consistent State practice and opinio juris reflect the customary nature of the first paragraph of Article 17 of the UDHR "[e]veryone has the right to own property alone as well as in association with others". The universal acceptance of general interest as a lawful limitation to the right to property (provided certain other conditions are met, as will be discussed in Part III), as illustrated by the concept of eminent domain itself, places the social function of property - which guarantees the realization of the core content of other economic, social and cultural rights - in the realm of customary norms. ${ }^{59}$ While preempting the further analysis, it can be said that stipulations of international and regional instruments, as well as the interpretation attributed to these by the supervisory bodies, in addition to the convergent juridical opinion of scholars and the evidence provided by consensually adopted resolutions of the UN General Assembly suggest that the payment of compensation in cases of unlawful and lawful deprivation of property has become a requirement of customary international law.

The controversial aspect that remains debated to these days refers to the standard of compensation applicable in cases of lawful expropriation. Section 3.4 of this study deals at length with this issue by looking at compensation and the general principles of international law.

\footnotetext{
${ }^{59}$ See for example W. B. Stoebuck's attempt to trace the historical and theoretical development of the concept of eminent domain, i.e. a taking of private property by the state in the general interest. W. B. Stoebuck, "A General Theory of Eminent Domain", 47 Washington Law Review 4, (1972), 553-608.
} 


\section{THE SCOPE AND CONTENT OF THE RIGHT TO PROPERTY AND CORRELATIVE STATES' OBLIGATIONS}

After the description of the provisions on the right to property in universal, regional and national instruments, we can conclude that the general acceptance of the right to property is beyond doubt. But the definition of the right to property varies in the different legal instruments, in particular with regard to its limitations, the allowed balancing of interests and the clauses on social aspects. We must therefore conclude that "the content of the right to property ultimately remains a question of interpretation by the supervisory organs" ${ }^{60}$ In this third part, the object, scope and content of this right, as well as the right holders, the standard of compensation and the correlative States' obligations, will be defined with the help of a jurisprudential analysis.

\subsection{The Object of the Right}

None of the universal and regional instruments discussed offers a clear-cut definition of the object of the right, i.e. property or, in the language of the ECHR, "possessions".

In the absence of the right to property being stipulated by the ICCPR, its supervisory organ - the Human Rights Committee (HRC) - has not dealt with the right directly. ${ }^{61}$ The extent to which the jurisprudence of the HRC is informative in relation to the content of the right is therefore minimal. Regional supervisory bodies, in contrast to international bodies, have been more prolific in this area.

The ECrtHR has given the term "possessions" a wide interpretation. Two important aspects ought to be mentioned here. First, the term may refer to "existing possessions" or assets, including claims in respect of which the applicant can argue that he or she has at least a "legitimate expectation" of obtaining effective enjoyment of a property right." ${ }^{\prime 62}$ It is clear however that the Court does not see any right to acquire property, as arising under the Protocol or the Convention. ${ }^{63}$ The Court takes the view that "the hope of recognition of a property right which it has been impossible to exercise effectively" and "conditional claim which lapses as a result of the non-fulfilment of the condition" lie outside the meaning of possessions of Article 1 of Protocol No.1. ${ }^{64}$ In Malhous vs. the Czech Republic, the Court concluded that Mr. Malhous could not have had any "legitimate expectation" of realizing his claim to restitution of his father's property, given that under the Land Ownership Act only those plots which were in the possession of the State or of a legal person could be returned, as opposed to those which had in the meantime been assigned to natural persons. ${ }^{65}$

\footnotetext{
${ }^{60}$ C. Krause, "The Right to Property", at 196.

${ }^{61}$ See for example Kéténguéré Ackla v. Togo, Communication No. 505/1992, U.N. Doc. CCPR/C/51/D/505/1992, 1996, para 6.3 , in which "the Committee noted that, irrespective of the fact that the confiscation took place prior to the date of entry into force of the Optional Protocol for Togo, the right to property was not protected by the Covenant. Accordingly, the Committee decided that this claim was inadmissible ratione materiae, under article 3 of the Optional Protocol."

62 Maltzan and others v. Germany, Applications nos. 71916/01, 71917/01 and 10260/02, Decision of 2 March 2005, para 74 (c); Kopecký v. Slovakia, Application No. 44912/98, Judgment of 28 September 2004, 35(c).

${ }^{63}$ See Slivenko and Others v. Latvia, Application no. 48321/99, Decision of 23 January 2002, para 121; Van der Mussele v. Belgium, Application no. 8919/80, Judgment of 23 November 1983, para 46.

${ }^{64}$ Maltzan and others v. Germany, Applications Nos. 71916/01, 71917/01 and 10260/02, Decision of 2 March 2005, para 74 (c); Kopecký v. Slovakia, Application No. 44912/98, Judgment of 28 September 2004, 35(c).

${ }^{65}$ Malhous v. the Czech Republic, Application No. 33071/96, Decision of 13 December 2000. See also Case of Prince HansAdam II of Liechtenstein v. Germany, Application No. 42527/98, Judgment of 12 July 2001, para 83.
} 
Looking at the object of the right to property, the Inter-American Court of Human Rights (IACrtHR) took a similar approach in the Five Pensioners case, in so far as it established the need for an "acquired" right in accordance with enacted legislation to exist ${ }^{66}$, or in the words of the InterAmerican Commission on Human and Peoples Rights, "an asset that formed part of the patrimony of the alleged victims" ${ }^{67}$

According to the IACrtHR, the "possession" of indigenous people is of a special character, since the "acquired by law" character is more lax:

1. Traditional possession of their lands by indigenous people has equivalent effects to those of a state-granted full property title.

2. Traditional possession entitles indigenous peoples to demand official recognition and registration of property title.

3. The members of indigenous people who have unwillingly left their traditional lands, or lost possession thereof, maintain property rights thereto, even though they lack legal title, unless the lands have been lawfully transferred to third parties in good faith; and

4. The members of indigenous peoples who have unwillingly lost possession of their lands, when those lands have been lawfully transferred to innocent third parties, are entitled to restitution thereof or to obtain other lands of equal extension and quality. Consequently, possession is not a requisite conditioning the existence of indigenous land restitution rights. ${ }^{68}$

The African Commission on Human and Peoples' Rights gave an almost identical interpretation to the property rights of indigenous people, when it concluded in its recent Endorois case that "possession is not a requisite condition for the existence of indigenous land restitution rights." ${ }^{69}$

The second aspect in respect to the object of property refers to its "autonomous meaning". ${ }^{70}$ The ECrtHR held that property covers both movable and immovable property, and is not limited to physical goods, nor is it dependent on formal classification in domestic law. ${ }^{71}$ Decisions of the Court have held that property includes, for example, contractual rights with economic value ${ }^{72}$, professional clientèl $e^{73}$, goodwill ${ }^{74}$, entitlement to compensation if certain criteria are met $^{75}$ and future income if it has been earned or is "definitely payable". ${ }^{76}$

\footnotetext{
66 "Five Pensioners" v. Peru, Judgment of 28 February 2003, para 103.

${ }^{67}$ Ibid, para 90.

${ }^{68}$ Sawhoyamaxa Indigenous Community v. Paraguay, Judgment of 29 March 2006, para 128.

${ }^{69}$ The relevant paragraph from the Commission's decision reads as follows: “(1) traditional possession of land by indigenous people has the equivalent effect as that of a state-granted full property title; (2) traditional possession entitles indigenous people to demand official recognition and registration of property title; (3) the members of indigenous peoples who have unwillingly left their traditional lands, or lost possession thereof, maintain property rights thereto, even though they lack legal title, unless the lands have been lawfully transferred to third parties in good faith; and (4) the members of indigenous peoples who have unwillingly lost possession of their lands, when those lands have been lawfully transferred to innocent third parties, are entitled to restitution thereof or to obtain other lands of equal extension and quality." Centre for Minority Rights Development (Kenya) and Minority Rights Group International on behalf of Endorois Welfare Council v. Kenya, Communication No. 276 / 2003, May 2009, para 209.

${ }^{70}$ Iatridis v. Greece, Application no. 31107/96, Judgment of 25 March 1999, para 54; Mayagna (Sumo) Awas Tingni Community v. Nicaragua, Judgment of 31 August 2001, para 146.

${ }^{71}$ See ECrtHR, The Concept of "Possessions", Key Case-Law Issues, 23 January 2007. See also A. Grgić, Z. Mataga, M. Longar and A. Vilfan, The right to property under the European Convention on Human Rights, Human Rights Handbook No. 10, Council of Europe, June 2007, at 6-9.

${ }^{72}$ C. Krause, "The Right to Property", at 199.

73 In Van Marle and Others v. The Netherlands, Application no. 8543/79; 8674/79; 8675/79; 8685/79, Judgment of 26 June 1986, para 41, the Court held that "by dint of their own work, the applicants had built up a clientèle; this had in many respects the nature of a private right and constituted an asset and, hence, a possession within the meaning of the first sentence of Article 1 (P1-1)".
} 
The IACrtHR, similarly, takes a wide view of the meaning of property:

[T]he term "property" used in said Article 21 includes "those material things which can be possessed, as well as any right which may be part of a person's patrimony; that concept includes all movables and immovables, corporeal and incorporeal elements and any other intangible object capable of having value $e^{\prime 77}$

In its recent decision in the Endorois case, the African Commission, while considering the autonomous meaning of property rights, recalled its views in the Ogoni case, where it found that the right to property “includes not only the right to have access to one's property and not to have one's property invaded or encroached upon, but also the right to undisturbed possession, use and control of such property however the owner(s) deem fit." ${ }^{\prime 78}$ It then goes on to take note of the ECrtHR practice according to which "property rights could also include the economic resources and rights over the common land of the applicants." ${ }^{79}$

As evidenced by the jurisprudence of the regional supervisory bodies, it appears straightforward and unquestionable that one of the key objects of property is land.

\subsection{The Right Holders}

The holders of the right to property under the ECHR are natural and legal persons. In Article 21, the ACHR recognizes the right of everyone to property. Following the precedent set by the Inter-

American Commission ${ }^{80}$, the IACrtHR has interpreted the provisions of this article as allowing for a communal or collective right of indigenous people, basing itself on the special spiritual link between indigenous people and their lands and their system of land ownership, which is not centered on an individual but on the group and its community. ${ }^{81}$ In its decision in the Moiwana case, in 2005, the Court extended the notion of collective property rights beyond indigenous people, hence recognizing other groups of individuals as right holders. ${ }^{82}$ The Court has upheld this position in a more recent case. ${ }^{83}$

${ }^{74}$ Ibid.

${ }^{75}$ Malhous v. the Czech Republic, Application no. 33071/96, Decision of 13 December 2000.

${ }^{76}$ Anheuser-Busch Inc. v. Portugal, Application no. 73049/01, Judgment of 11 January 2007, para 64.

${ }^{77}$ Yakye Axa Indigenous Community v. Paraguay, Judgment of 17 June 2005, para 137.

${ }^{78}$ Centre for Minority Rights Development (Kenya) and Minority Rights Group International on behalf of Endorois Welfare Council v. Kenya, Communication No. 276 / 2003, May 2009, para 86.

${ }^{79}$ Ibid.

${ }^{80}$ See F. MacKay, "From 'Sacred Commitment' to Justiciable Norms: Indigenous Peoples Rights in the Inter-American System", in A. Tostensen and W. Vandenhole (eds.), Casting the Net Wider-Human Rights and Development in the 21st Century, Antwerp, Intersentia, 2007, 371-394, at 374-378.

${ }^{81}$ Mayagna (Sumo) Awas Tingni Community v. Nicaragua, Judgment of 31 August 2001, para 148 and 153, 149; Yakye Axa Indigenous Community, Judgment of 17 June 2005, para 143.

82 N'Djuka clans are a community of Maroons, descendants of African slaves which settled in the Moiwana Village in the late $19^{\text {th }}$ century. This ethnic community did not possess legal title to the land inhabited and Suriname argued that the property belonged to the State. While admitting that the N'Djuka did not constitute an indigenous people the Court held, after hearing testimonies from anthropologists that the groups "all-encompassing relationship" to their traditional lands through a system of communal ownership entitled them to a collective right to property that the State was under a duty to recognize. Comunidad Moiwana Vs. Suriname, Sentencia, 15 de junio de 2005, para 132, 134. See also K. de Feyter, "Treaty Interpretation and the Social Sciences", in F. Coomans, F. Grünfeld, and M. T. Kamminga (eds.), Methods of Human Rights Research, Antwerp, Intersentia, 2009, at 228-229.

${ }^{83}$ Saramaka People. v. Suriname, Judgment of 28 November 2007, para 102. 
Article 14 of the AfCHPR does not specify a subject of the right to property. ${ }^{84}$ However, its reading in light of Article $2^{85}$ and the case-law of the African Commission on Human and Peoples' Rights ${ }^{86}$, clarifies beyond question that every individual has the right to property under the Charter. In its recent case, after having established that the Endorois "are 'a people', a status that entitles them to benefit from provisions of the African Charter that protect collective rights" ${ }^{\prime 87}$, the Commission recognizes "the right to property with regard to its ancestral land, the possessions attached to it, and their animals" of the Endorois community. ${ }^{88}$ The African Commission thus explicitly acknowledges a right to communal property in the case of indigenous people.

In light of historic discriminatory practices, women as property rights holders deserve special attention. In Marckx v. Belgium, a case concerning discriminatory inheritance practices, the ECrtHR found a violation of Article 1 of Protocol No. 1 "by reason of the fact that an unmarried mother is not free to dispose of her property in favour of her child." The Court's comment is paradigmatic: In view of Article 14 of the Convention, the Court fails to see on what "general interest", or on what objective and reasonable justification, a State could rely to limit an unmarried mother's right to make gifts or legacies in favour of her child when at the same time a married woman is not subject to any similar restriction. ${ }^{89}$

A number of relevant cases at national, regional and international levels deal, inter alia, with inheritance customary rights that discriminate between men and women, and with discriminatory provisions related to the administration of the communal property within marriage. ${ }^{90}$

\subsection{The Content of the Right to Property}

To define the right to property, the ECrtHR enunciated three rules in Sporrong and Lönnroth $v$. Sweden in 1982, which have become the fundamentals of the content of the right to property in the European system and are at the basis of an abundant jurisprudence in the field of property rights. According to the ECrtHR:

Article (P1-1) comprises three distinct rules. The first rule, which is of a general nature, enounces the principle of peaceful enjoyment of property; it is set out in the first sentence of the first paragraph. The second rule covers deprivation of possessions and subjects it to certain conditions; it appears in the second sentence of the same paragraph. The third rule recognizes that the States are entitled, amongst other things, to control the use of property

\footnotetext{
${ }^{84}$ C. Krause, "The Right to Property", at 199.

${ }^{85}$ Article 2 of the AfCHPR provides that: "[e]very individual shall be entitled to the enjoyment of the rights and freedom recognized and guaranteed in the [...] Charter".

${ }^{86}$ See for example John K. Modise v. Botswana, Communication No. 97/93, 2000, para 94.

${ }^{87}$ Centre for Minority Rights Development (Kenya) and Minority Rights Group International on behalf of Endorois Welfare Council v. Kenya, Communication No. 276 / 2003, May 2009, para 161-162.

88 Ibid., para 184.

${ }^{89}$ Marckx v. Belgium, Application No. 6833/74 of 13 June 1979, para 65. Article 14 of the ECHR reads: "the enjoyment of the rights and freedoms set forth in this Convention shall be secured without discrimination on any ground such as sex, race, colour, language, religion, political or other opinion, national or social origin, association with a national minority, property, birth or other status".

${ }^{90}$ See for example Graciela Ato del Avellanal v. Peru, Communication No. 202/1986, U.N. Doc. Supp. No. 40, A/44/40, 1998, at 196; Sonia Arce Esparza v. Chile, Case 71/01, Report No. 59/03. See also Report on the Rights of Women in Chile: Equality in the Family, Labour and Political Spheres, OEA/Ser.L/V/II.134, Doc. 63, 27 March 2009, para 5. For several cases decided by the Supreme Court of India on customary law governing the transfer of property, see R. Emerton et al. (eds.), International Women's Rights Cases, London, Cavendish, 2005, at xxxv - xxxvii.
} 
in accordance with the general interest, by enforcing such laws as they deem necessary for the purpose; it is contained in the second paragraph. ${ }^{91}$

Interference of property, while allowed, must satisfy certain conditions cumulatively: the principle of legality, a general or public interest character and a proportionality test. The principle of legality includes that interference must be prescribed by law, but the law must also be published and accessible and gather certain qualitative characteristics to be "compatible with the rule of law". ${ }^{92}$ The lawful interference of the individual's property rights must also pass the test of legitimacy, in other words it needs to be pursued in the general or public interest. Under the margin of appreciation doctrine, the Court has in the past often deferred to the interpretation of general interest given by States in the context of property rights. ${ }^{93}$ In James v. the United Kingdom, the ECrtHR made a seminal assessment:

Because of their direct knowledge of their society and its needs, the national authorities are in principle better placed than the international judge to appreciate what is "in the public interest". (...) Furthermore, the notion of "public interest" is necessarily extensive. (...) [T]he decision to enact laws expropriating property will commonly involve consideration of political, economic and social issues on which opinions within a democratic society may reasonably differ widely. The Court, finding it natural that the margin of appreciation available to the legislature in implementing social and economic policies should be a wide one, will respect the legislature's judgment as to what is "in the public interest" unless that judgment be manifestly without reasonable foundation. ${ }^{94}$

As we will see below, the notion of public or general interest, which allows a balance of interest to fulfill the social function of property, is therefore particularly significant in the context of the realization of economic and social rights (see Part IV).

The condition of proportionality is also related to the general interest character of the interference. This refers to the reasonable relationship of proportionality which must exist between the means employed and the aim sought to be realized. The ECrtHR takes the view that an instance of interference should strike "a 'fair balance' between the demands of the general interest of the community and the requirements of the protection of the individual's fundamental rights". ${ }^{95}$ In practice, although the ECrtHR is said to have employed a lax standard of proportionality, variations are observable. In respect to the control of property (third rule) the Court sets the standard of proportionality at a lower level - consequently allowing for a wider margin of appreciation to States - than in cases related to deprivation or expropriation (second rule). ${ }^{96}$

\footnotetext{
${ }^{91}$ Sporrong and Lönnroth, Application no. 7151/75; 7152/75, Judgment of 23 September 1982, para 61. (Emphases added).

92 James and others v. The United Kingdom, Application no. 8793/79, Judgment of 21 February 1986, para 67. See also A. Grgić et al., The Right to Property under the European Convention on Human Rights, at 12-13. In a recent case, after having found that Romania's restitution law is "surabondante et ... largement inefficace" the Court goes on to indicate, "[p]our aider l'État défendeur à remplir ses obligations au titre de l'article 46", what normative and legislative measures should put in place in order to achieve "un juste équilibre entre les différents intérêts en jeu." Viaşu c. Roumanie, Requête $\mathrm{n}^{\circ}$ 75951/01 du 9 décembre 2008, para 72, 83.

${ }_{93}$ See for example James and others v. The United Kingdom, Application No. 8793/79, Judgment of 21 February 1986; Former King of Greece and others v. Greece, Application No. 25701/94, Judgment of 23 November 2000.

See also M. Hutchinson, "The Margin of Appreciation Doctrine in the European Court of Human Rights", 48 International and Comparative Law Quarterly 3, 2008, at 640.

${ }^{94}$ James and others $v$. The United Kingdom, Application no. 8793/79, Judgment of 21 February 1986, para 46. For a commentary, see also M. Carss-Frisk, The Right to Property, Human Rights Handbooks No. 4, Council of Europe 2001, at 2628.

${ }^{95}$ Tre Traktörer Aktiebolag v. Sweden, Application no. 10873/84, Judgment of 07 July 1989, para 46.

${ }^{96} \mathrm{Y}$. Arai-Takahashi, The Margin of Appreciation Doctrine and the Principle of Proportionality in the Jurisprudence of the ECHR, Antwerp, Intersentia, 2002, at 148.
} 
While in the past the African Commission did not have the possibility to address the right to property in many $\operatorname{cases}^{97}$, recent jurisprudential developments are revealing in terms of the Commission's interpretation of the content of this right stipulated by the African Charter. In the 2009 Endorois case, the Commission dealt extensively with the right to property and set out a "twopronged test" entailing that an encroachment must be "in the interest of public need or in the general interest of the community" and "in accordance with appropriate laws" ${ }^{98}$, the latter referring to both domestic and international law. ${ }^{99}$ At the same time, it set out that the limitations on property rights must be reviewed under the principle of proportionality, i.e. the interference with property rights must be "proportionate to a legitimate need, and should be the least restrictive measure possible." ${ }^{100}$ Also, it would appear that the ancestral land of indigenous people belongs to a special category of property, and as the African judicial body puts it " $t$ t]he 'public interest' test is met with a much higher threshold in the case of encroachment of indigenous land rather than individual private property. In this sense, the test is much more stringent when applied to ancestral land rights of indigenous people." ${ }^{101}$

\subsection{Compensation and the General Principles of International Law}

As has been underlined, the issue of compensation in connection to the right to property has been a thorny one during the drafting process of several human rights instruments. Whereas the ACHR and the AfCHPR (albeit only in Article 21) have certain provisions on compensation, the European Convention and its First Protocol lack such provisions. For example, the IACrtHR based itself on the $\mathrm{ACHR}$ and on the "principle of international law that any violation of an international obligation which has caused damage carries with it the obligation to provide adequate reparation for it" in issuing decisions regarding compensation. ${ }^{102}$

In the ECHR-context, given the silence of the Convention, there was stringent need for clarification through the jurisprudence of the ECrtHR. Thus, the Court noted that protection offered by property rights would be "largely illusory and ineffective" in the absence of compensation. ${ }^{103}$ In the jurisprudence of the ECrtHR since the 1980s, it has therefore become generally accepted that in cases of deprivation, compensation is implicitly required. As Theo van Banning observes, since both deprivation and control are forms of limiting the right to property, "ideally there should not be a substantial difference" between the two, nonetheless in "actual practice there is a strong tradition whereby deprivation normally leads to compensation and control does not lead to compensation." ${ }^{104}$ Nonetheless, in Chassagnou v. France, a case dealing with control, while assessing

\footnotetext{
${ }^{97}$ In the Modise case, for example, the Commission found a violation of the right to property, but it did not address its content because the Government of Botswana had not refuted the allegation of having confiscated belongings and property of Mr. Modise. For the Commission: "It is trite law that where facts go uncontested by a party, in this case, the Respondent State, such would be taken as given". John K. Modise v. Botswana, Communication No. 97/93 (2000), para 94.

${ }^{98}$ Centre for Minority Rights Development (Kenya) and Minority Rights Group International on behalf of Endorois Welfare Council v. Kenya, Communication No. 276 / 2003, May 2009, para 211.

${ }^{99}$ Ibid, para 219.

100 Ibid, para 214.

101 Ibid, para 212.

102 Mayagna (Sumo) Awas Tingni Community v. Nicaragua, Judgment of 31 August 2001, para 153.

103 James and others v. The United Kingdom, Application no. 8793/79, Judgment of 21 February 1986, para 54.

${ }^{104}$ T. R. G. van Banning, The Human Right to Property, at 102.
} 
proportionality the Court noted the lack of adequate compensation and went on to find a violation of the right to property. ${ }^{105}$

Having seen that compensation has become an integral part of the proportionality test in respect to property rights ${ }^{106}$, even in the absence of an express mentioning in the ECHR, the standards according to which the level of compensation is established must be addressed. In this context, Lithgow and Others $v$. the United Kingdom is a relevant case, which helps frame the discussion. The case concerns the nationalization of certain interests of several ship and aircraft building companies by the UK government. The applicant companies did not contest the legitimate aim of the nationalization, however they claimed that the received compensation was "grossly inadequate" and that they had been victims of breaches of [inter alia] Article 1 of Protocol No. $1 .{ }^{107}$ The British Government had decided upon a compensation system that valued the applicants' shares by reference to their value three years prior to the date of the actual transfer of shares; it was reckoned that such a system of compensation would avoid a value that could be artificially affected by the knowledge of the nationalization. ${ }^{108}$ In respect to this reasoning the Court made some important findings:

The taking of property without payment of an amount reasonably related to its value would normally constitute a disproportionate interference which could not be considered justifiable under Article 1 (P1-1). Article 1 (P1-1) does not, however, guarantee a right to full compensation in all circumstances, since legitimate objectives of "public interest", such as pursued in measures of economic reform or measures designed to achieve greater social justice, may call for less than reimbursement of the full market value. ${ }^{109}$

It follows thus, that the market value, or to be precise, "an amount reasonably related" to this value, is the general standard according to which compensation in cases involving taking of property ought to be paid. Nonetheless, as the Court clearly specified, full compensation is not a guaranteed right. ${ }^{110}$ Pursuing economic reform or greater social justice may qualify as legitimate measures of general interest which may require less than the reimbursement of the full market price of the property at stake. This interpretation, which acknowledges the important social function property plays within societies, is coherent with earlier and later judgments of the European Court. ${ }^{111}$

\footnotetext{
${ }^{105}$ The case was brought by ten landowners who had the exclusive hunting rights on their land. The French legislature considered that it would be in the general interest to make smaller landowners form an association granting hunting rights to all concerned over their land put together. However, the applicants, who were animal-welfare activists opposed to hunting, claimed that the compulsory transfer of hunting rights infringed their right to property as protected by Article 1 of Protocol I of the ECHR. As the Court observed, compensating landowners with the ability to hunt on the land of others "is valuable only in so far as all the landowners concerned are hunters or accept hunting." Chassagnou v. France, Applications nos. 25088/94, 28331/95 and 28443/95, Judgment of 29 April 1999, para 82. See also M. Carss-Frisk, The Right to Property, at 38 .

${ }^{106}$ As has been pointed out above, this applies at least in the cases of deprivation.

107 Lithgow and Others v. the United Kingdom, Application no. 9006/80; 9262/81; 9263/81;9265/81; 9266/81; 9313/81; 9405/81, Judgment of 8 July 1986.

108 Ibid. See also M. Carss-Frisk, The Right to Property, at 39.

${ }^{109} \mathrm{Ibid}$, at 121.

${ }^{110}$ It should be mentioned here that in cases of deprivation which are deemed unlawful full compensation according to the market value of the property is required. See for example Former King of Greece and others v. Greece, Application no. 25701/94, Judgment (Just satisfaction) of 28 November 2002, para 75-79; Scordino v. Italy (No.1), Application no. 36813/97, Judgment of 29 March 2006, para 250-253.

${ }^{111}$ See for example James and others v. The United Kingdom, Application no. 8793/79, Judgment of 21 February 1986, para 54 and Holy Monasteries v. Greece, Application nos. 13092/87; 13984/88, Judgment of 09 December 1994, para 71.
} 
Moreover, the Court asserts that the standard of compensation may vary depending on the nature of the property and the circumstances of the taking and that the wide margin of appreciation which the State enjoys applies to the assessment weather the deprivation of property is in the public interest as well as to the terms of compensation. ${ }^{112}$

Another important aspect relevant to the level of compensation debate, which received attention in Lithgow and Others $v$. the United Kingdom, refers to the "general principles of international law". The applicants claimed that the express mention in the second sentence of Article 1 of Protocol 1 to the general principles of international law meant that the international law requirement of "prompt, adequate and effective compensation for the deprivation of property of foreigners also applied to nationals." ${ }^{113}$ The European judges, building on previous case law and the travaux préparatoires, firmly asserted their view that "the principles in question are not applicable to a taking by a State of the property of its own nationals", but "solely to non-nationals". ${ }^{114}$ According to the official record then "the general principles of international law, in their present connotation, entailed the obligation to pay compensation to non-nationals in cases of expropriation". ${ }^{115}$

A manual on compensation in international investment law observes that the compatibility of the European Court's jurisprudence with the disputes heard by investment tribunals is "somehow limited" by the preponderance in the ECrtHR of cases brought by nationals against their own States. ${ }^{116}$ However, the authors - in a statement echoing the need to stop or rather limit the fragmentation of the international legal system - acknowledge the potential of the ECHR as an international legal instrument and of the interpretation given to it by the European Court "to inform international dispute settlement generally" ${ }^{117}$

The attempt to disclose the general principles of international law in relation to the standards of compensation ${ }^{118}$ should begin by recalling the 1928 Chorzów Factory Case, so often cited by tribunals in cases of deprivation of property of foreign nationals and companies. The case decided upon by the Permanent Court of International Justice (PCIJ) concerned the Polish unlawful expropriation of German-owned industrial property within Poland. According to the Court, the principles which should serve to determine the amount of compensation due for an act contrary to international law are the following:

[R]eparation must, as far as possible, wipe out all the consequences of the illegal act and reestablish the situation which would, in all probability, have existed if that act had not been committed. Restitution in kind, or, if this is not possible, payment of a sum corresponding to the value which a restitution in kind would bear; the award, if need be, of damages for loss sustained which would not be covered by restitution in kind or payment in place of it. ${ }^{119}$

\footnotetext{
112 Lithgow and Others v. the United Kingdom, Application No. 9006/80; 9262/81; 9263/81;9265/81; 9266/81; 9313/81; 9405/81, Judgment of 8 July 1986, para 121 and 122.

${ }^{113} \mathrm{lbid}$, para 111. Hence, their assertion was that in similar cases in general international law it is the date of taking which is considered as the date of assessment. Therefore, they claimed that the relevant date for assessing the value of the shares - which had actually increased in the period leading to the actual transfer - should be closer to the date of taking. M. Carss-Frisk, The Right to Property, at 39.

${ }^{114}$ See Ibid, para 111-119. See also James and others v. The United Kingdom, Application No. 8793/79, Judgment of 21 February 1986, para 58-66.

${ }^{115}$ Ibid, para 117, respectively para 64.

${ }^{116}$ S. Ripinsky with K. Williams, Damages in International Investment Law, London, British Institute of International and Comparative Law, 2008, at 83.

${ }^{117}$ Ibid.

118 Issues related to the actual valuation of property in arbitration cases are beyond the scope of this paper.

${ }^{119}$ The Factory at Chorzów, Germany v. Poland, Merits, Judgment No. 13, 1928, P.C.I.J., Series A, No. 17, p. 47.
} 
The PCIJ distinguishes between lawful and unlawful expropriation, while outlining the requirement of full compensation in the context of an illegal taking of property. This historic distinction has been taken over by the International Law Commission in its work in codifying international law in respect to compensation required as a consequence of expropriation. In this sense, the Draft Articles on State Responsibility deal with takings amounting to wrongful acts of states and explicitly exclude lawful expropriations. ${ }^{120}$

The remaining debate then refers to the standard of compensation, or in other words how much compensation should be awarded, in cases of lawful deprivation of property. In the 1930s already, the PCIJ standard has been extrapolated to cases of legal takings, termed as the "Hull formula" and seen as equivalent ${ }^{121}$ to the "prompt, adequate and effective" requirement. ${ }^{122}$ The strongest contestation of the Hull formula came during the 1960s and 1970s. Most States that emerged from the process of decolonization expressed their "permanent sovereignty over natural resources [...] primarily through large-scale nationalization of mineral extraction facilities, the renegotiation of existing arrangements and the creation of state enterprises and numerous commodity producer associations." ${ }^{123}$ A series of UN General Assembly resolutions which were promoted and strongly supported by developing and socialist States are evidence of the conceptual rift that emerged in relation to the applicable standard of compensation. In 1962, resolution 1803 on Permanent Sovereignty over Natural Resources affirmed the right to nationalize foreign owned property and required the nationalizing State to pay "appropriate compensation": ${ }^{124}$

Nationalization, expropriation or requisitioning shall be based on grounds or reasons of public utility, security or the national interest which are recognized as overriding purely individual or private interests, both domestic and foreign. In such cases the owner shall be paid appropriate compensation, in accordance with the rules in force in the State taking such measures in the exercise of its sovereignty and in accordance with international law. ${ }^{125}$

The vagueness of the term "appropriate" and the requirement that compensation be attributed in accordance with international law are said to have made consensus in the General Assembly possible at that time ${ }^{126}$ However, already then two divergent positions had become evident. Developed countries maintained that "appropriate" was to be interpreted according to traditional principles of international law and hence the Hull formula. Developing States insisted that it ought to be read in the light of relevant circumstances and compensation should be awarded in accordance to the national law of the expropriating State (the Calvo doctrine). ${ }^{127}$ The 1974 Charter of Economic

\footnotetext{
${ }^{120}$ International Law Commission, Commentaries on Articles on Responsibility of States for Internationally Wrongful Acts, 2001, UN Doc. A/56/10, at 31. In addition to full compensation, after establishing that at stake is a case of illegal taking some tribunals have awarded compensation for lost profits. See for Libyan American Oil Company v. Libyan Arab Republic, ('LIAMCO v. Libya'), 62 ILR 140, 1977, at 202-203.

${ }^{121}$ Although not all authors share this opinion, see for a notable challenge of such equation O. Schachter, "Compensation Cases - Leading and Misleading", 79 American Journal of International Law, (1985), 420 - 422.

${ }^{122}$ The name comes from that of the US Secretary of State Cordell Hull, who in the context of the nationalization by Mexico of property owned by US nationals wrote in the 1930s that international law provided for payment "prompt, adequate and effective compensation". See OECD, “'Indirect Expropriation' and the 'Right to Regulate' in International Investment Law", Working Paper on International Investment, No. 2004/4, September 2004.

${ }^{123}$ Permanent Sovereignty Over Natural Resources, Report of the Secretary-General, UN Doc. E/C.7/1983/5, 1983, at 3 as quoted in R. B. Lillich, "The Law Governing Disputes Under Ecibinu Development Agreements: Reexamining the Concept of 'Internationalization'", in R. B. Lillich and C. N. Brower (eds.), International Arbitration in the $21^{\text {st }}$ Century: Towards "Judicialization" and Uniformity?, Irvington, New York, Twelfth Sokol Colloquium, 1993, at. 111.

${ }^{124}$ Permanent Sovereignty over Natural Resources, G.A. res. 1803 (XVII), U.N. Doc. A/5217, 1962.

125 Ibid, para 4.

${ }^{126}$ S. Ripinsky with K. Williams, Damages in International Investment Law, at 72. ${ }^{127}$ Ibid.
} 
Rights and Duties of States while employing the term "appropriate" left out any reference to the need for compensation to be paid in accordance with international law. ${ }^{128}$ The resolution aiming to establish a New International Economic Order represented in fact the peak of the disagreement between the North and the South on the issue of the standard of compensation. While it had been portrayed as a rejection of international law by some authors ${ }^{129}$, de Arechaga notes that this description of the General Assembly resolution 3281 is "not entirely accurate":

Though expelled through the door because of its alleged identification with the doctrine of "prompt, adequate and effective compensation", [international law] has come back through the window in the garb of an equitable principle which takes into account the specific circumstances of each case and is more likely to be of assistance in the settlement of investment disputes through negotiation or, if the parties so agree, through adjudication. ${ }^{130}$

In Texaco v. Libya, the arbitrator, while asserting that by virtue of the consensual nature of resolution 1803 "appropriate compensation" had become the new customary standard, dismissed the resolution 3281 as de lege feranda. ${ }^{131}$ Given the lack of a general and consistent State practice and the divergence within doctrine, it is rather difficult to hold the "appropriate compensation" requirement as it has been interpreted by developing countries as the customary principle in relation to compensation. Nonetheless, it would be equally difficult - in the presence of strong opposition from developing States - to hold the traditional requirement of "prompt, adequate and effective compensation" as a continued expression of customs. What can be noted however is the "large degree of flexibility and discretion" which the "appropriate compensation" formula grants to arbitrators "allowing them to rely on various considerations including equity, balanced outcome, capacity of a State to pay". ${ }^{132}$

The post-Cold War period has seen a tremendous increase in bilateral investment treaties, the majority of which are said to contain reference to the "adequate" standard as part of the Hull formula, which thus call for compensation equivalent to the market value. ${ }^{133}$ However, it is also noted that some treaties include specific mention of "just" and/or "equitable" compensation, which hence suggest the possibility of tribunals to take other circumstance into account during arbitration. ${ }^{134}$ Sergey Ripinsky and Kevin Williams recommend caution while inferring from the current proliferation of bilateral investment treaties and their preference for the Hull formula the clear return to the traditional general principle of "prompt, adequate and effective compensation" assessed on the basis of market value of the expropriated investment. They conclude that "customary international law is not fully settled on the issue of compensation for lawful expropriation". ${ }^{135}$

\footnotetext{
${ }^{128}$ Charter of Economic Rights and Duties of States, GA Res. 3281 (XXIX), UN Doc. A/9631, 1974.

${ }^{129}$ See for example A. Lowenfeld, International Economic Law, Oxford, Oxford University Press, 2002, at 413. See also B. J. Weston, "The New International Economic Order and the Deprivation of Property Wealth: Reflections upon the Contemporary International Law Debate", in R. B. Lillich (ed.), International Law of State Responsibility for Injuries to Aliens, Charlottesville, University Press of Virginia, 1983, at 101.

${ }^{130}$ E. J. de Arechaga, "State Responsibility for the Nationalization of Foreign Owned Property", 11 Journal of International Law and Politics, 1978, at 188-189.

${ }^{131}$ See for example Texaco Overseas Petroleum Co v. Libyan Arab Republic ('Texaco v. Libya'), 53 ILR 389, 1973.

${ }^{132}$ S. Ripinsky with K. Williams, Damages in International Investment Law, at 74. Equity has been expressly used as a principle in the case of Libyan American Oil Company v. Libyan Arab Republic ('LIAMCO v. Libya'), 62 ILR 140, 1977, at 149 150.

${ }^{133}$ S. Ripinsky with K. Williams, Damages in International Investment Law, at 78-79.

${ }^{134}$ Ibid.

${ }^{135}$ Ibid, at $78-80$ and 83.
} 


\subsection{Correlative States' Obligations}

The jurisprudence of the main three regional judicial bodies is consistent with the fact that both "negative and positive" obligations of States arise under the respective Conventions in respect to property rights.

The "negative" duty of the State to respect the right to property amounts to an abstention of interference with the right. In the European system, State actions such as expropriation, de jure or de facto, temporary seizure of property, destruction of property, rent controls, and planning restrictions have been held, under certain circumstances, to represent a breach of the obligation to respect the right to property. ${ }^{136}$

In recent years, the ECrtHR has also dealt with several cases where it found that "the genuine, effective exercise of the right protected by Article 1 of Protocol No. 1 does not depend merely on the State's duty not to interfere, but may give rise to positive obligations". ${ }^{137}$ Öneryildiz $v$. Turkey is an illustrative example. The applicants lived in a slum quarter in Istanbul built without authorization next to a rubbish tip. An expert report pointed to the fact that the tip represented a danger for the slum inhabitants in the absence of measures preventing a methane explosion. In 1993, a methane explosion occurred, which killed nine close relatives and destroyed the house of the applicants. In respect to the right to property, the ECrtHR stated:

In the Court's view, the resulting infringement amounts not to "interference" but to the breach of a positive obligation, since the State officials and authorities did not do everything within their power to protect the applicant's proprietary interests. ${ }^{138}$

In its jurisprudence, the Court has also held that the positive obligation of States to protect property rights continues to exist in cases involving litigation between private entities. For example, States are required to take concrete measures to put in place a judicial mechanism for settling effectively property disputes and to ensure that such a mechanism complies with the material and procedural safeguards enshrined in the Convention. ${ }^{139}$

Although the ECrtHR does not acknowledge a right to acquire property ${ }^{140}$, in James and Others $v$. the United Kingdom the Court employs language that resonates with the States' obligation to fulfill. The applicants in this case were trustees of the estate of the Duke of Westminster who owned a large number of houses in London. They complained that they lost a considerable amount of money as a result of the implementation of the Leasehold Reform Act, which gave tenants with lease of 21 years the possibility to buy the houses under the market price. In short, the ECrtHR granted a wide margin of appreciation to the Government both in respect to the aim and to the measures undertaken to secure the aim, based on the following reasoning:

Eliminating what are judged to be social injustices is an example of the functions of a democratic legislature. More especially, modern societies consider housing of the population to be a prime social need, the regulation of which cannot entirely be left to the play of market forces. The margin of appreciation is wide enough to cover legislation aimed at

\footnotetext{
${ }^{136}$ A. Grgić et al., The right to property under the European Convention on Human Rights, at 9.

137 Sierpiński v. Poland, Application no. 38016/07, Judgment of 3 November 2009, para 68. See also Öneryıldız v. Turkey, Application no. 48939/99, Judgment of 30 November 2004, para 135; Broniowski v. Poland, Application no. 31443/96, Judgment of 22 June 2004, para 143.

138 Öneryıldız v. Turkey, Application no. 48939/99, Judgment of 30 November 2004, para 135

139 Sierpiński v. Poland, Application no. 38016/07, Judgment of 3 November 2009, para 69.

${ }^{140}$ See supra (Section 3.1, the object of the right).
} 
securing greater social justice in the sphere of people's homes, even where such legislation interferes with existing contractual relations between private parties and confers no direct benefit on the State or the community at large. ${ }^{141}$

In its important decision in the Awas Tingni case, the IACrtHR clearly took the position that a State has both negative and positive obligations under the relevant provisions of the ACHR. The Court found that the Awas Tingni indigenous community "has the right that the Nicaraguan State carry out the delimitation, demarcation, and titling of the territory" ${ }^{142}$, which indeed amounts to a positive State obligation.

In the African continent, the Ogoni case deserves particular attention for the integrated approach that the African Commission took, also in respect of the correlative State's obligations. The complaint alleged that the military Government of Nigeria has been directly involved in oil production through the State oil company in a consortium with Shell Petroleum Development Corporation (SPDC), whose activities in the Ogoni region caused environmental contamination, health problems and a climate of terror. The communication lodged by two non-governmental organizations on behalf of the Ogoni people alleged violations of many articles of the AfCHPR, including Article 14 (right to property) and Article 21 (right of peoples to freely dispose of their wealth and natural resources). It was further alleged that the Government condoned and facilitated the violations by placing the legal and military authorities at the disposal of the company. Moreover, the Nigerian security forces allegedly contributed to the violations by attacking and burning villages and homes. It was alleged that the State failed to investigate and punish the perpetrators. After making appeal to foreign case-law, the African Commission emphasized the duty of States to protect their citizens "not only through appropriate legislation and effective enforcement but also by protecting them from damaging acts that may be perpetrated by private parties".${ }^{143}$ It then continued, stating the following:

The Commission notes that in the present case, despite its obligation to protect persons against interferences in the enjoyment of their rights, the Government of Nigeria facilitated the destruction of the Ogoniland. Contrary to its Charter obligations and despite such internationally established principles, the Nigerian Government has given the green light to private actors, and the oil Companies in particular, to devastatingly affect the well-being of the Ogonis. By any measure of standards, its practice falls short of the minimum conduct expected of governments, and therefore, is in violation of Article 21 of the African Charter. ${ }^{144}$

In its most recent decision involving the property rights of the Endorois indigenous community, the African Commission analyzed the usual framework of States obligations - respect, protect, fulfill and made a case for the legality and indeed the requirement to, in certain circumstance, redress imbalances through positive discrimination or affirmative action. ${ }^{145}$

To sum up this section on the correlative States' obligations in respect to the right to property, appeal will be made to another emblematic statement of the African Commission:

\footnotetext{
141 James and others v. The United Kingdom, Application no. 8793/79, Judgment of 21 February 1986, para 47.

142 Mayagna (Sumo) Awas Tingni Community v. Nicaragua, Judgment of 31 August 2001, para 153.

143 Social and Economic Rights Action Center \& the Center for Economic and Social Rights v. Nigeria, Communication No. 155/96, 27 May 2002, para 57.

144 Ibid, para 58. For an analysis of the case, see F. Coomans, "The Ogoni case before the African Commission on Human and Peoples' Rights", 52 International and Comparative Law Quarterly 3, 2008, 749-760.

${ }^{145}$ Centre for Minority Rights Development (Kenya) and Minority Rights Group International on behalf of Endorois Welfare Council v. Kenya, Communication No. 276 / 2003, May 2009, para 196.
} 
[A]Il rights-both civil and political rights and social and economic-generate at least four levels of duties for a State that undertakes to adhere to a rights regime, namely the duty to respect, protect, promote, and fulfil these rights. These obligations universally apply to all rights and entail a combination of negative and positive duties. ${ }^{146}$

\section{THE RIGHT TO PROPERTY AND THE PROTECTION OF ECONOMIC, SOCIAL AND CULTURAL RIGHTS}

As the 1993 report of the Independent Expert "on the right of everyone to own property alone as well as in association with others" points out, the right to property is not an isolated right, but one which is instrumental in "enhancing both personal dignity and fostering socio-economic wellbeing." ${ }^{147}$ Jurisprudence of regional bodies appears to support this claim. Three economic, social and cultural rights will be addressed in the remainder of this paper in connection to the right to property: the right to housing, the right to food and the right to social security.

\subsection{The Right to Property and the Right to Housing}

The link between property and housing is indeed so obvious that it requires little explanation. The ECrtHR has produced abundant case-law on the right to property as a means of protecting one's house. ${ }^{148}$ Similarly, the Inter-American Commission and the Court dealt with confiscation of houses under Article 21. ${ }^{149}$ The African Commission too has addressed the protection of one's house as part of the right to property. ${ }^{150}$

The use of property rights as a means to further the right to housing, or indeed to obtain redress for violations of housing rights, is perhaps best illustrated by cases related to forced evictions. In Doğan and Others v. Turkey, the applicants complained that their forced eviction from their village in SouthEastern Turkey by security forces and the refusal of the authorities to allow them to return to their homes and land represents a violation of their property rights protected by Article 1 of Protocol $1 .{ }^{151}$ The European Court, "in the view of the security motives by the Government", left open the

\footnotetext{
${ }^{146}$ Social and Economic Rights Action Center \& the Center for Economic and Social Rights v. Nigeria, Communication No. 155/96, 27 May 2002, para 44.

${ }^{147}$ The right of everyone to own property alone as well as in association with others. Completed final report submitted by Mr. Luis Valencia Rodríquez, Independent Expert, UN Doc. E/CN.4/1994/19, 25 November 1993, para 116.

${ }^{148}$ We have previously referred to Öneryıldız v. Turkeyi, Application no. 48939/99, Judgment of 30 November 2004. There are also a number of cases dealing with actions of recovery of houses. See for example Brumărescu v. Romania, Application No. 28342/95, Judgment of 28 October 1999. Other examples are cases in which it was alleged that houses of Kurds were burnt by Turkish security forces. See for example Akdivar and Others v. Turkey, Application Nos. 99/1995/605/693, Judgment of 1 April 1998.

${ }^{149}$ Melish observes that most of these cases involved individual property-holders whose houses or lands were expropriated by the State without just compensation, and hence the dispute centered primarily on issues of just compensation. T. J. Melish, "The Inter-American Commission on Human Rights: Defending Social Rights Through CaseBased Petitions", in M. Langford (ed.), Social Rights Jurisprudence: Emerging Trends in Comparative and International Law, New York, Cambridge University Press, 2008, at 33.

${ }^{150}$ Malawi African Association and Others v. Mauritania, Communication nos. 54/91, 61/91, 98/93, 164/97 à 196/97 and 210/98, 2000.

${ }^{151}$ Doğan and Others v. Turkey, Application nos. 8803-8811/02, 8813/02 and 8815-8819/02, Judgment as rectified on 18 November 2004, para 134.
} 
question regarding the lawfulness of the interference. ${ }^{152}$ The ECrtHR concluded that the applicants had to bear an "excessive burden which has upset the fair balance which should be struck between the requirements of the general interest and the protection of the right to the peaceful enjoyment of one's possessions." ${ }^{\prime 153}$ In reaching its conclusion, the Court highlighted in particular the Principles 18 and 28 of the UN Guiding Principles on Internal Displacement. ${ }^{154}$ The former principle requires the authorities to provide internally displaced persons with, and ensure access to, inter alia, basic shelter and housing, as a component of an adequate standard of living. Principle 28 refers to procedural requirements, such as the consultation with and the full participation of displaced persons in the authorities' attempt to resettle and reintegrate them.

Similarly, the African Commission takes a strict stance while asserting that forced evictions "cannot be deemed to satisfy Article 14 of the Charter's test of being done 'in accordance with the law' [...] [w] here such removal was forced, this would in itself suggest that the 'proportionality' test has not been satisfied." ${ }^{\prime 155}$ In the recent Endorois case, it reached this conclusion while making reference to standards outlined by the Committee on Economic, Social and Cultural Rights in its General Comment 4 on the right to housing and General Comment 7 on evictions and the right to housing. ${ }^{156}$

In the jurisprudence of the African system, the Ogoni case presents particular interest for the current opinion, given the integrated approach embraced by the Commission to allow for a greater protection of economic and social rights. The African Commission expressly asserted that the right to shelter or housing - not mentioned by the Charter - can be distinguished from the "combined effects" of Article 14, 16 and 18. In the words of the Commission:

[T] he 'corollary of the combination of the provisions protecting the right to enjoy the best attainable state of mental and physical health, (...) the right to property, and the protection accorded to the family forbids the wanton destruction of shelter because when housing is destroyed, property, health, and family life are adversely affected. ${ }^{157}$

The African Commission went on to assert massive violations of the right to shelter "under Article 14 and implicitly recognized by Article 16 and 18(1)". ${ }^{158}$

Adding another dimension to the link between property and housing, Krause suggests that positive measures, which are related to the duty to fulfill the right to housing, might be in conflict with a strong protection of the right to property. ${ }^{159}$ According to the jurisprudence of the ECrtHR, measures related to rent legislation or the possibility of acquiring a previously leased house at advantageous prices, promoted by the State in order to achieve greater social justice and fulfill the right to housing, have been accepted by the Court as having legitimate aims. In Mellacher and others $v$. Austria, the applicants who owned several flats rented to tenants complained that the implementation of legislation that resulted in a reduction of the rent infringed their right to property under Article 1 of Protocol No.1. The ECrtHR found that the aim of the interference was legitimate and the measure proportionate:

\footnotetext{
152 Ibid, para 149.

153 Ibid, para $154-155$.

${ }^{154}$ Ibid. See the Guiding Principles on Internal Displacement, UN Doc. E/CN/41998/53/Add.2, 1998.

${ }^{155}$ Centre for Minority Rights Development (Kenya) and Minority Rights Group International on behalf of Endorois Welfare Council v. Kenya, Communication No. 276 / 2003, May 2009, para 218.

${ }^{156}$ Ibid, para 200.

157 Social and Economic Rights Action Center \& the Center for Economic and Social Rights v. Nigeria, Communication No. 155/96, 27 May 2002, para 60.

${ }^{158}$ Ibid, para 59.

${ }^{159}$ C. Krause, "The Right to Property", at 208.
} 
The Court observes that, in remedial social legislation and in particular in the field of rent control, which is the subject of the present case, it must be open to the legislature to take measures affecting the further execution of previously concluded contracts in order to attain the aim of the policy adopted. ${ }^{160}$

It thus appears that the Court is prepared to grant large discretion to States when they exercise their obligation to limit the right to property to fulfill the right to housing.

\subsection{The Right to Property and the Right to Food}

Unquestionably, there is an intrinsic link between property, land and food. It is this link, which the African Commission emphasized in the Ogoni case, which makes the right to property and the right to food intimately interdependent.

On the issue of land property rights functioning as a means to realize the right to food, the jurisprudence of the Inter-American Commission and the Court is particularly relevant. In 1996, after having been unsuccessful in their attempt to regain their ancestral land, which was also an important source for their food, the Enxet-Lamenxay and Kayleyphapopyet (Riachito) communities filed a petition with the Inter-American Commission alleging violations of the rights to judicial protection, fair trial, property, residence and the benefits of culture under the ACHR. ${ }^{161}$ In 1998 , a friendly settlement agreement was signed, under which the State committed itself to purchasing approximately 22,000 hectares in the Paraguayan Chaco region, returning them to the communities and providing the deeds of ownership. The State also guaranteed to provide food, sanitary and educational assistance. ${ }^{162}$

In other cases, the IACrtHR interpreted Article 21 of the Convention in light of the economic, social, and cultural rights of indigenous communities. ${ }^{163}$ On numerous occasions, it interpreted the right to property of indigenous peoples as requiring a positive obligation of the State to delimitate and demarcate the land, and protect the communal rights to property, to allow them to provide for their own means of subsistence. ${ }^{164}$ The Yakye $A x a^{165}$ and the Sawhoyamaxa ${ }^{166}$ cases are emblematic to present the evolutionary approach of the Court. In the latter case, the Sawhoyamaxa indigenous community, being denied its right to its ancestral lands, was forced to live in appalling conditions with limited access to food. As a consequence of these conditions, 31 members of the community, among them many children, died. ${ }^{167}$ As a general principle, the Court asserted that "[t]he right to life is a fundamental human right, which full enjoyment is a prerequisite for the enjoyment of the other human rights. If this right is not respected, all other rights do not have sense."168 After looking into

\footnotetext{
${ }^{160}$ Mellacher and others v. Austria, Application no. 10522/83; 11011/84; 11070/84, Judgment of 19 December 1989, para 47 and 51. See also James and others v. The United Kingdom, Application no. 8793/79, Judgment of 21 February 1986, para $47 \mathrm{ff}$.

${ }^{161}$ Enxet-Lamenxay and Kayleyphapopyet (Riachito), Case No. 11.713. Report No. 90/999, para 10-12.

162 Ibid, para 10-15.

${ }^{163}$ M. Tinta, "Justicability of Economic, Social, and Cultural Rights in the Inter-American System of Protection of Human Rights: Beyond Traditional Paradigms and Notions", 29 Human Rights Quarterly 2, 2007, at 449.

${ }^{164}$ F. MacKay, "From 'Sacred Commitment' to Justiciable Norms: Indigenous Peoples Rights in the Inter-American System", at 378-379. See also C. Golay, The Right to Food and Access to Justice: Examples at the National, Regional and International Levels, FAO, 2009, at 42-45.

165 Yakye Axa Indigenous Community v. Paraguay, Judgment of 17 June 2005.

${ }^{166}$ Sawhoyamaxa Indigenous Community v. Paraguay, Judgment of 29 March 2006.

167 Ibid, para 3.

168 Ibid, para 150.
} 
whether Paraguay has adopted "the necessary measures within the scope of its authority which could be reasonably expected to prevent or avoid the risk to the right to life of the alleged victims $^{\prime 169}$ the Court found that:

[A]lthough the State did not take them to the side of the road, it is also true it did not adopt the adequate measures, through a quick and efficient administrative proceeding, to take them away and relocate them within their ancestral lands, where they could have used and enjoyed their natural resources, which resources are directly related to their survival capacity and the preservation of their ways of life. ${ }^{170}$

At the end of its reasoning, the Court concluded that Paraguay violated several articles of the ACHR, including Article 4(1) on the right to life and Article 21 on the right to property.

The aim of this section was to analyze cases of property rights that have served to further the right to food. In this context, it is appropriate to recall the recent attempt made by the Special Rapporteur on the right to food at guiding large-scale land acquisition and leases by proposing a set of principles that would bring land property purchases in accordance with the right to food and other human rights. ${ }^{171}$

\subsection{The Right to Property and the Right to Social Security}

Litigation in respect to the right to property has also been started as a route to enforce different dimensions of the right to social security, with a particular emphasis on pensions. In the past, the European Commission had held that Article 1 of Protocol No. 1 does not guarantee a right to pension, but went on to assert that the compulsory contribution to a pension fund may in certain circumstances create a property right in a portion of the fund. ${ }^{172}$ This condition had given rise to serious complexities. ${ }^{173}$ More recently, in a crucial decision, the ECrtHR refuted this approach and stated that there are no grounds upon which to draw a distinction between contributory and noncontributory benefits for the purposes of the applicability of Article 1 of Protocol No. $1 .{ }^{174}$ In the case at hand, Stec and Others $v$. the United Kingdom, a complaint had been brought under the right to property provision of the First Protocol in conjunction with Article 14 of the ECHR, prohibiting inter alia sex-discrimination. In addition to renouncing to the differentiation doctrine between contributory and non-contributory schemes, the Court made another major assertion. Whereas pension or other social benefits cannot be implied, as such, under the right to property in the European system, the ECrtHR held that if a State has a legislation in force providing for the payment of a welfare benefit as a right, "that legislation must be regarded as generating a proprietary interest falling within the ambit of Article 1 of Protocol No. 1 for persons satisfying its requirements." ${ }^{175}$ In Moskal v. Poland, in 2009, the Court upheld its reasoning and clarified that a pension right claim which is not brought in connection with Article 14, but only as an alleged interference of the property rights alone, is admissible. And it concluded that Article 1 was violated. ${ }^{176}$

\footnotetext{
169 Ibid, para 153.

$170 \mathrm{lbid}$, at para 164.

${ }^{171}$ Large-scale land acquisitions and leases: A set of core principles and measures to address the human rights challenge, Mr. Olivier De Schutter Special Rapporteur on the right to food, 11 June 2009.

${ }^{172}$ A. R. Çoban, Protection of property rights within the European Convention on Human Rights, London, Ashgate 2004, at 157-158.

${ }^{173}$ For a critical view of the approach taken by the Commission, see C. Krause, "The Right to Property", at 206.

${ }^{174}$ Stec and Others v. the United Kingdom, Applications nos. 65731/01 and 65900/01, Decision of 6 July 2005, para 53.

${ }^{175}$ Ibid, para 54.

${ }^{176}$ Moskal v. Poland, Application no. 10373/05, Judgment of 15 September 2009, para 46 and 76.
} 
In the Five Pensioners Case, the IACrtHR concluded that the right to a pension existed since it has been recognized by the Peruvian Constitution and it had been incorporated in the patrimoine of the persons. In this sense, "Article 21 (Right to Property) of the Convention protects the right of the five pensioners to receive an equalized retirement pension in accordance with Decree Law No.

$20530 "{ }^{177}$ The Court went on to discuss the aim of the interference and found it legitimate under Article 21 and Article 5 of the San Salvador Protocol, but it asserted that the measures taken by the State were arbitrary because it did not execute administrative procedures with full respect for the appropriate guarantees and it did not comply with the judicial rulings arising from their applications for protective measures. ${ }^{178}$

\footnotetext{
177 "Five Pensioners" v. Peru, Judgment of 28 February 2003, para 102.

${ }^{178}$ Ibid, para 116-117, 121.
} 


\section{CONCLUSION}

The right to property has been enshrined as a human right in international law - both conventional and customary - through universal and regional treaties and national constitutions. The right to property recognizes everyone's right to peacefully enjoy their property, be it comprised of existing possessions or assets acquired by law or claims which raise a legitimate expectation of obtaining effective enjoyment. The right protects individual property, as well as, at least in the case of the Inter-American and African systems, communal property. Limitations of the right are permissible, provided that they respect the principles of legality and proportionality and that they are directed towards assuring or advancing the public or general interest. Human rights law recognizes both positive and negative state obligations related to the right to property.

\subsection{Compensation}

The payment of compensation in cases of deprivation is a requirement of customary international law. However, the standard according to which compensation is to be awarded remains debated. In the view of the authors of this paper, the standard should reflect all branches of international law relevant to the subject-matter, including investment law and human rights law. Moreover, the customary standard of compensation ought to be coherent with the functions fulfilled by the right to property with respect to the individual and society at large.

\section{2. $\quad$ Right to Property}

The right to property is essential for the protection of human life and dignity of the right holder as it contributes to the realization of economic and social rights including the right to housing, to food and to social security. On the other hand, given the inherent social function of the right to property, this right may be limited in order to resolve social injustices and advance the economic, social and cultural rights of specific disadvantaged individuals or groups. ${ }^{179}$

\subsection{Obligation to Respect the Right to Property}

The obligation to respect the right to property requires that States refrain from arbitrarily interfering with the enjoyment of the right. Expropriation without legal basis or not in the public interest is an example of a violation of the obligation to respect the right to property.

\subsection{Obligation to Protect the Right to Property}

The obligation to protect the right to property requires States to take all necessary measures including legislative, administrative and judicial, to prevent encroachment by third parties. The failure to protect individuals against expulsion from or destruction of their property, or the failure to delimitate and demarcate the communal land of indigenous people, could amount to a violation of the right to property.

\footnotetext{
${ }^{179}$ See for example, ECrtHR, James and others v. The United Kingdom, Application no. 8793/79, Judgment of 21 February 1986, para 47.
} 


\subsection{Obligation to Fulfil the Right to Property}

The obligation to fulfil the right to property requires States to undertake positive steps, legislative and otherwise, to create an enabling environment. ${ }^{180}$ For example, in a country characterized by extreme inequalities in access to property, failure of the State to take corrective measures could represent a violation of the obligation to fulfil the right to property.

${ }^{180}$ See for example, South African Constitution of 1996, Art. 25(5) 


\section{TABLE OF CASES}

\section{African Commission on Human and Peoples' Rights}

- Centre for Minority Rights Development (Kenya) and Minority Rights Group International on behalf of Endorois Welfare Council v. Kenya, Communication No. 276 / 2003, May 2009, para 209

- John K. Modise v. Botswana, Communication No. 97/93, 2000

- Malawi African Association and Others v. Mauritania Communication nos. 54/91, 61/91, 98/93, 164/97 à 196/97 and 210/98, 2000

- Social and Economic Rights Action Center \& the Center for Economic and Social Rights v. Nigeria, Communication 155/96, 27 May 2002

\section{European Court of Human Rights}

- Akdivar and Others v. Turkey, Application nos. 99/1995/605/693, Judgment of 1 April 1998

- Anheuser-Busch Inc. v. Portugal Application no. 73049/01, Judgment of 11 January 2007

- Broniowski v. Poland Application no. 31443/96, Judgment of 22 June 2004

- Brumărescu v. Romania Application no. 28342/95, Judgment of 28 October 1999

- Case of Prince Hans-Adam II of Liechtenstein v. Germany Application no. 42527/98, Judgment of 12 July 2001

- Chassagnou v. France, Applications nos. 25088/94, 28331/95 and 28443/95, Judgment of 29 April 1999

- Doğan and Others v. Turkey, Application nos. 8803-8811/02, 8813/02 and 8815-8819/02, Judgment as rectified on 18 November 2004

- Former King of Greece and others v. Greece, Application no. 25701/94, Judgment of 23 November 2000

- Handyside v. The United Kingdom Application no. 5493/72, Judgment of 7 December 1976

- latridis v. Greece Application no. 31107/96, Judgment of 25 March 1999

- Ihsan Bilgin v. Turkey, Application no. 23819/94, Judgment of 16 November 2000

- James and others $v$. The United Kingdom, Application no. 8793/79, Judgment of 21 February 1986

- Kopecký v. Slovakia Application No. 44912/98, Judgment of 28 September 2004

- Lithgow and Others v. the United Kingdom, Application no. 9006/80; 9262/81; 9263/81;9265/81;9266/81; 9313/81; 9405/81, Judgment of 8 July 1986

- Malhous v. the Czech Republic Application no. 33071/96, Decision of 13 December 2000

- Maltzan and others v. Germany Applications nos. 71916/01, 71917/01 and 10260/02, Decision of 2 March 2005

- Marckx v. Belgium Application no. 6833/74, Judgment of 13 June 1979

- Moskal v. Poland Application no. 10373/05, Judgment of 15 September 2009

- Öneryıldız v. Turkey Application no. 48939/99, Judgment of 30 November 2004

- Sierpiński v. Poland Application no. 38016/07, Judgment of 3 November 2009

- Slivenko and Others v. Latvia Application no. 48321/99, Decision of 23 January 2002

- Sporrong and Lönnroth Application no. 7151/75; 7152/75 Judgment of 23 September 1982

- Stec and Others v. the United Kingdom, Applications nos. 65731/01 and 65900/01, Decision of 6 July 2005

- Tre Traktörer Aktiebolag v. Sweden Application no. 10873/84, Judgment of 07 July 1989

- Van der Mussele v. Belgium Application no. 8919/80, Judgment of 23 November 1983 
- Van Marle and Others v. The Netherlands Application no. 8543/79, 8674/79, 8675/79, 8685/79, Judgment of 26 June 1986

- Viaşu c. Roumanie Requête no. 75951/01 de 9 décembre 2008

- Holy Monasteries v. Greece Application nos. 13092/87, 13984/88, Judgment of 9 December 1994

\section{Human Rights Committee}

- Graciela Ato del Avellanal v. Peru, Communication No. 202/1986, U.N. Doc. Supp. No. 40, $\mathrm{A} / 44 / 40$, at 196,1988

Inter-American Court of Human Rights and the Inter-American Commission of Human Rights

- Enxet-Lamenxay and Kayleyphapopyet (Riachito), Case no. 11.713. Report No. 90/999

- "Five Pensioners" v. Peru, Judgment of 28 February 2003

- Comunidad Moiwana v. Suriname, Sentencia, 15 de junio de 2005

- Mayagna (Sumo) Awas Tingni Community v. Nicaragua, Judgment of 31 August 2001

- Saramaka People. v. Suriname, Judgment of 28 November 2007

- Sawhoyamaxa Indigenous Community v. Paraguay, Judgment of 29 March 2006

- Sonia Arce Esparza v. Chile, Case 71/01, Report No. 59/03

- The Yakye Axa Indigenous Community v. Paraguay, Judgment of 17 June 2005

\section{Investment Arbitration Tribunals}

- Ebrahimi, Shahin Shain v. Islamic Republic of Iran ('Ebrahimi v. Iran'), 30 Iran-US Claims Tribunal 170, 1994

- Libyan American Oil Company v. Libyan Arab Republic ('LIAMCO v. Libya'), 62 ILR 140, 1977

- Texaco Overseas Petroleum Co v. Libyan Arab Republic ('Texaco v. Libya'), 53 ILR 389, 1973

\section{Permanent Court of International Justice}

- The Factory at Chorzów, Germany v. Poland, Merits, Judgment No. 13, 1928, P.C.I.J., Series A, No. 17 